Политология

DOI: $10.17117 /$ na.2016.08.01.383

http://ucom.ru/doc/na.2016.08.01.383.pdf

Поступила (Received): 24.08.2016

\title{
Вагина В.O.
}

\section{Проблема патриотизма современных граждан России}

\author{
Vagina V.O. \\ The problem of patriotism of modern Russian citizens
}

В статье рассматривается проблема нравственного состояния молодежи. Проблема патриотического воспитания молодежи актуальна как никогда, в условиях утраты нашим обществом традиционного российского патриотического сознания, широкого распространения равнодушия, цинизма, агрессивности и падения престижа военной службы формируется комплекс ущербности и неполноценности нации

Ключевые слова: индивидуализм, национализм, массовая культура

\section{Вагина Виктория Олеговна}

Студент

Южный федеральный университет

2. Ростов-на-Дону, Пушкинская, 160

\begin{abstract}
This article focuses on the problem of the moral state of youth. The problem of patriotic education of youth is more relevant than ever. In terms of loss of our society traditional Russian patriotic consciousness, widespread indifference, cynicism, aggressiveness and falling prestige of military service formed the complex of inferiority and inadequacy of the nation
\end{abstract}

Key words: individualism, nationalism, popular culture

\author{
Vagina Victoria Olegovna \\ Student \\ Southern federal university \\ Rostov-on-Don, Pushkinskaya, 160
}

Начиная с 80-х годов, в обществе происходили сложные процессы: резко замедлились темпы развития экономики, произошла утрата прежних идеологических ориентиров, усилились агрессивность среды, социальная нестабильность, изменился характер общения между людьми, что было связано с утратой традиций общинности, взаимопомощи и взаимной поддержки. Выявилось все нарастающее отчуждение молодежи от официально пропагандируемых социальных ценностей, школы, семьи. Однодетная, конфликтная, нередко неполная семья перестала полноценно выполнять воспитательные функции. Молодежь все более остро ощущала невостребованность обществом знаний и таланта. Постепенный размыв, «истончение» культурного слоя, культурных традиций, интеллигентности, снижение ценности такого явления как патриотизм - эти и другие подобные факторы значительно затрудняли осуществление эффективной образовательной политики. Развал старой системы воспитания привел к тому, что, не усвоив ценность патриотизма и коллективизма, молодое поколение формировалось на ценностях крайнего индивидуализма и эгоизма [2, c. 16-18]. 
Патриотизм представляет собой своего рода фундамент общественного и государственного здания, опору его жизнеспособности, одно из первостепенных условий эффективности функционирования всей системы социальных и государственных институтов. Усвоение ценностей и норм жизни, утвердившихся в обществе, - объективный, но не стихийный процесс.

Патриотизм не заложен в генах, это не природное, а социальное качество и потому не наследуется, а формируется. Одной из важнейших задач современности является формирование понятия Родина, Отечество, Отчизна. Родина включает в себя все многообразие социальных и природных факторов, которые мы называем понятиями семья, микрорайон или деревня, город или район. По мере своего развития каждый из нас постепенно осознает свою принадлежность к семье, коллективу, народу. Вершиной патриотического воспитания является осознание себя гражданином России. Как невозможно научить любви к родителям одними призывами, так невозможно воспитать гражданина из школьника, изучавшего большую Родину только по книгам. Патриотизм должен воспитываться в постоянном общении с родной природой, широком знакомстве с социальными условиями жизни народа.

Но как обстоят дела с патриотизмом у нынешней молодежи? Патриотизм, развитию которого раньше посвящали много усилий, постепенно превратился из необходимого элемента воспитания подрастающих поколений, во что-то лишнее, несовременное. К развитию патриотизма у молодежи относились всё более формально, отбивая тем самым желание быть патриотом и вызывая сомнение в целесообразности данного личностного качества. Развал старой системы воспитания привел к тому, что, не усвоив ценность патриотизма и коллективизма, молодое поколение формировалось на ценностях крайнего индивидуализма и эгоизма. Падение коммунистического режима в России не могло означать только смену политического порядка или господствующей идеологии. Важнейшей составляющей этого процесса явилось разрушение устоявшихся представлений советских людей о себе и своем месте в мире, вызвавшее массовый кризис идентичности и, как следствие, разрушение основ советского патриотизма. Таким образом, новое поколение начинало свою жизнь в стране, в которой напрочь отсутствовала какая либо идеология или система ценностей. Поскольку ничего в нашем мире не терпит пустоты, образовавшийся вакуум быстро стал заполняться технологиями разрушения национального самосознания. К их числу прежде всего относятся: либерально-рыночная доктрина; «массовая культура» с ее культом насилия, эгоизма, секса, антиинтеллектуализма; система давления на общественное мнение, вызывающая апатию, безразличие; внедрение деструктивных религиозных сект и учений и т.д. Как только личность отрывается от целого (социальная среда, нация, Родина), она неизбежно попадает в ловушку ценностей, лишенных общественного, гражданского содержания. Это основа развития эгоизма личности. Если общество не интересуют проблемы личности, то ответной реакцией незащищенной личности становится агрессия против общества, антиобщественное поведение в различных формах: преступность, терроризм, наркомания и т. п. Человек в современной 
России с одной стороны, стремится жить в обществе, исповедующем традиционные ценности, и в то же время пользоваться достижениями современной науки и техники. В России столкнулись две системы ценностей - либеральная, которая пришла на смену социалистической как ее антитеза; и традиционная, складывавшаяся на протяжении многих веков. В результате этого значительно увеличилось число людей, для которых стала характерной социокультурная амбивалентность, связанная с раздвоением ценностного сознания, проявляющаяся в одновременном стремлении к противоположным ценностям [4, с. 20-23].

Как известно, когда свободы чересчур много, она развращает человека. Так материальные ценности стали преобладать над моральными. Что считает ценным среднестатистический молодой человек? Деньги, машину, хорошую одежду, вечеринки по выходным... Для патриотизма в этом случае совсем не остается места. И почти никто не задумывается, что так жить нельзя. Самое интересное заключается в том, что молодежь понимает и принимает патриотизм как ценность, но слабо представляет его на практике. Отсутствуют достойные примеры патриотизма в современном обществе, а если и есть, о них не принято напоминать молодежи.

В сознании советских людей был прочно сформирован образ защитника Отечества, Добра, справедливости (сказочный, собирательный и реальный); образ жизни подвижника, образ мудрости государственного деятеля, образ воли полководца. Мощным фактором воспитания был образ героя (А.Матросов, М.Паникаха, З.Космодемьянская, пионеры-герои и др.) и образ героического акта (переход через линию фронта, оборона дома Павлова и др.)... Данные образы предстают как образцы патриотизма, нравственности, духовности, толерантности, самоотверженности, мужества, воли к победе и т.д. [3, с. 111-114].

Хотелось бы упомянуть об еще одной проблеме патриотизма современной молодежи. Сегодня все больше и больше начинают говорить о патриотизме, о патриотических чувствах россиян. И это закономерно. Любовь к Родине стала мощным эмоциональным побудительным мотивом в общественном сознании, значимом для различных социальных групп. Патриотизм стал своего рода защитной реакцией по отношению к пропагандируемым в последнее десятилетие тезисам, что «Россия неспособна к цивилизованному развитию» и ее ждет «беспросветность впереди». Такой патриотизм называют «реактивным патриотизмом». Он возникает как ответная реакция на различного рода национальное, культурное, религиозное, территориальное ущемление. Распад СССР, поражение в «холодной войне», падение авторитета нашей страны на международной арене, локальные военные конфликты, всё это стало питательной средой для роста такого неестественного сознания и чувства, воплощённого в формы образов врагов, предателей, диссидентов. Такой патриотизм очень распространен, особенно в молодежной среде. Среди тех, кто называют себя патриотами, таких около 90\%, явление это достаточно опасное, так как у таких людей присутствует некий комплекс неполноценности, его еще называют «Homo Soveticus». Он проявляется в том, что человек чувствует некое превосходство западного человека, к примеру, тот лучше одевается или ездит на более дорогой машине. Защитная 
реакция может проявляться в самых разных формах - вплоть до крайнего национализма, шовинизма и ксенофобии. И в этом-то как раз и заключается третья проблема патриотизма современной молодежи. Не каждый способен отличить настоящий патриотизм от других понятий, им прикрывающимся. Патриотизм не противостоит осознанию человеком своей принадлежности ни к своему этносу, ни ко всему человечеству. Патриотизм заключается в том, чтобы любить свой народ и уважать другие народы. Патриотизм - это не движение против чего-либо, а движение за те ценности, которыми располагает общество и человек. Патриотизм - это, прежде всего, состояние духа, души. Патриотизм - это когда ты любишь свой народ, а национализм - это когда ты ненавидишь другие народы. И каждый из нас должен осознать разницу в этих понятиях.

Патриотизм у современной молодежи переживает не самые легкие времена. Об этом свидетельствует факт концентрации государственного интереса к проблемам воспитания патриотизма у граждан Российской Федерации, что закреплено государственной программой. Перечисленные проблемы могут и должны решаться не завтра и не в следующем году, а прямо сейчас. Россия должна либо духовно возродиться, либо исчезнуть. Завтрашний день России зависит от того, насколько выверенными и дальновидными будут принимаемые сегодня меры по воспитанию патриотизма в подрастающем поколении [1, с. 89].

\section{Список используемых источников:}

1. Левашов В.К. Патриотизм в контексте современных социально-политических реалий // Социс. М., 2006. №8. С. 8-9.

2. Пишет, как живет. М., 2002. № 10. С.16-18.

3. Подберезкин А.И. Русский путь. М., 1997. С. 111-114.

4. Семенов В.Е Ценностные ориентации современной молодежи // Социс. М., 2007. №4. С. 20-23.

(c) 2016, Вагина B.O.

Проблема патриотизма современных граждан

России
(C) 2016, Vagina V.O.

The problem of patriotism of modern Russian citizens 